JOANNA SZEAPIŃSKA

Uniwersytet im. Adama Mickiewicza

$w$ Poznaniu

\title{
WSPÓŁCZESNY KSZTAŁT PEDAGOGIKI PRACY W POLSCE
}

\begin{abstract}
Szłapińska Joanna, Wspótczesny kształt pedagogiki pracy w Polsce [Contemporary Status of Pedagogy of Work in Poland]. Studia Edukacyjne nr 37, 2015, Poznań 2015, pp. 153-168. Adam Mickiewicz University Press. ISBN 978-83-232-2967-4. ISSN 1233-6688. DOI: 10.14746/se.2015.37.10

The article raises basic issues of the test subject pedagogy of work which deals with relations between a man, his upbringing and knowledge, thanks to which he acquires education, various qualifications and competencies and professional work based on lifelong learning. The article is directed primarily to students of pedagogy of work - fundamental subject at pedagogical studies, students of related studies in the field of professional orientation, guidance and job counseling and students of other pedagogy specializations. The author's considerations assume a historical view of the test subject, the main tasks of the theoretical research of the pedagogy of work.
\end{abstract}

Key words: pedagogy of work, labor market, historical view of pedagogy of work, science of work, problem areas of research

\section{Wprowadzenie}

Artykuł porusza podstawowe zagadnienia z zakresu przedmiotu badań pedagogiki pracy, która zajmuje się relacjami pomiędzy człowiekiem, jego wychowaniem i nauką, dzięki której zdobywa wykształcenie, różnorodne kwalifikacje i kompetencje a pracą zawodową, opartą na całożyciowym uczeniu się. Współczesne wymogi rynku pracy nie gwarantują pewności i stałości pracy. Liczba zarejestrowanych bezrobotnych w Polsce, w urzędach pracy, w końcu marca 2015 roku wyniosła 1 860,6 tys. osób (w tym 938,7 tys. kobiet) ${ }^{1}$. Rosnąca liczba bezrobotnych sprawiła, że praca zaczęła być postrzegana jako towar deficytowy. W konsekwencji, posiadanie za-

1 Bezrobocie rejestrowane, I kwartał 2015 r., GUS, Warszawa 2015 na: file:///C:/ Users/WSE/Downloads/bezrobocie_rejestrowane_1kw2015.pdf [dostęp: 1.08.2015]. 
trudnienia rosło $\mathrm{w}$ hierarchii pożądanych wartości społecznych. Idea „uczenia się przez całe życie" stała się zatem koniecznością, aby uzyskać i utrzymać pracę.

Niniejszy artykuł jest skierowany przede wszystkim do studentów pedagogiki pracy - przedmiotu podstawowego na studiach pedagogicznych, studentów pokrewnych specjalności z zakresu orientacji zawodowej, doradztwa i poradnictwa zawodowego, a także do studentów wszystkich innych specjalności pedagogicznych, bowiem rozważania autorki zakładają ukazanie rysu historycznego, przedmiotu badań, głównych zadań teoretyczno-badawczych dyscypliny pedagogicznej jaką jest pedagogika pracy.

\section{Przedmiot pedagogiki pracy}

Pedagogika pracy należy do grupy nauk o pracy. Zaliczamy ją do subdyscyplin pedagogicznych, których przedmiotem badań są pedagogiczne aspekty relacji: człowiek-wychowanie-praca ${ }^{2}$. Według Z. Wiatrowskiego, przedmiotem badań pedagogiki pracy są relacje: człowiek-obywatel-pracownik $^{3}$. Zasadniczym pojęciem pedagogiki pracy jest praca rozumiana jako wartość uniwersalna - punkt odniesienia do innych wartości.

Encyklopedia pedagogiczna definiuje pedagogikę pracy jako „dyscyplinę naukową, obejmującą całość problematyki pedagogicznej, wynikającej z zetknięcia człowieka z pracą" ${ }^{4}$. Przeciwieństwem tej lakonicznej i ogólnikowej formuły jest definicja słownikowa W. Okonia, który skupia swą uwagę na przedmiocie badań pedagogiki pracy, rozszerzając tym samym zakres znaczeniowy definiowanego pojęcia. Pedagogika pracy, według W. Okonia, to

dyscyplina pedagogiczna, której przedmiotem badań jest praca ludzka, jej różnorodne uwarunkowania, jej wpływ wychowawczy na jednostkę, a więc wpływ automatyzacji produkcji na człowieka, znaczenie pracy wytwórczej w kształceniu ogólnym, dostosowanie stanowiska pracy do człowieka, przystosowanie pracownika do warunków jego pracy5.

Pedagogika pracy to dyscyplina pedagogiczna, której przedmiotem badań jest praca ludzka, jej różnorodne uwarunkowania, jej wpływ wychowawczy na jednostkę, znaczenie pracy w kształceniu ogólnym, dostosowa-

2 S.M. Kwiatkowski, Pedagogika pracy jako subdyscyplina pedagogiczna, [w:] Pedagogika pracy, red. S.M. Kwiatkowski, A. Bogaj, B. Baraniak, Warszawa 2007, s. 13.

${ }^{3}$ Z. Wiatrowski, Podstawy pedagogiki pracy, Bydgoszcz 2005, s. 33.

${ }^{4}$ W. Pomykało (red.), Encyklopedia pedagogiczna, Warszawa 1996, s. 565.

${ }^{5}$ W. Okoń (red.), Nowy stownik pedagogiczny, Warszawa 2001, s. 289. 
nie stanowiska pracy do człowieka, przystosowanie pracownika do warunków pracy ${ }^{6}$.

W Leksykonie pedagogiki pracy (2004) czytamy: pedagogika pracy w Polsce

została pomyślana jako dyscyplina, badająca stosunek człowieka i pracy pod kątem przygotowania do pracy. Zajmuje się więc problemami: wychowania przez pracę, kształcenia politechnicznego, doskonalenia ogólnego i zawodowego pracowników 7 .

W najnowszym wydaniu podręcznika akademickiego Podstawy pedagogiki pracy (2005), Z. Wiatrowski poszerza definicję pedagogiki pracy o wyznaczniki, zawierające kryteria odrębności i samodzielności dyscypliny naukowej, które spełnia pedagogika pracy. Są to:

- wyraźnie sprecyzowany i społecznie znaczący przedmiot badań i zainteresowań badawczych;

- odpowiednie do przedmiotu - terminologia i nazewnictwo;

- logicznie zwarty system pojęć i twierdzeń;

- dostosowana do przedmiotu metodologia badań, w tym metody, techniki i narzędzia oraz procedury badań;

- określona płaszczyzna przebiegu i przetwarzania informacji naukowej (wydawnictwa, kontakty krajowe i zagraniczne);

- powszechnie uznana reprezentacja instytucjonalna i personalna.

W następstwie powyższych ustaleń i wymagań naukoznawczych,

pedagogikę pracy przyjęło się [zdaniem Z. Wiatrowskiego] określać jako subdyscyplinę naukową, której przedmiotem badań są pedagogiczne aspekty relacji: człowiek - wychowanie - praca, chociaż często akcentuje się też drugą relację trójczłonową: człowiek - obywatel - pracownik, jako również dobrze oddającą istotne problemy i zadania tej nowej dyscypliny pedagogicznej ${ }^{8}$.

Z tak sformułowanej definicji pedagogiki pracy wynika, iż o przedmiocie tej nowej subdyscypliny naukowej decydują wzajemne układy, relacje i związki przedmiotowo-treściowe, którym przyświeca przede wszystkim koncepcja całościowego przygotowania człowieka - pracownika - obywatela do pracy zawodowej (od funkcji rodziny, przedszkola i szkoły począwszy), poprzez całościowe wychowanie i kształcenie „w pracy, do pracy i przez pracę" do wszechstronnego, udanego, satysfakcjonującego udziału w procesie pracy zawodowej pracownika, obywatela, a jednocześnie - człowieka.

Bardzo wnikliwą definicję pedagogiki pracy podaje A. Bogaj, który nazywa ją subdyscypliną pedagogiki, badającą różne aspekty pracy w wycho-

\footnotetext{
${ }^{6}$ J.E. Karney, Podstawy psychologii i pedagogiki pracy, Pułtusk 2004, s. 27.

7 T.W. Nowacki, Leksykon pedagogiki pracy, Radom 2004, s. 174.

8 Z. Wiatrowski, Podstawy, s. 32-33.
} 
waniu człowieka - m.in. sens i przemiany pracy ludzkiej, prace jako wartość, jakość pracy, jej wpływ na jednostkę, wybór zawodu, aktywność zawodową jednostek, drogi awansu zawodowego, kształcenie a rynek pracy, standardy kwalifikacji zawodowych, kształcenie ustawiczne, znaczenie, funkcje i rolę pracy w procesach kształcenia i wychowania9.

Z kolei J.E. Karney, psycholog pracy i pedagog pracy, uważa, że obydwie dziedziny wiedzy (psychologia pracy i pedagogika pracy) wzajemnie się łączą $\mathrm{w}$ tzw. psychopedagogikę pracy i są równoważne w wyjaśnianiu faktów, procesów i wzajemnych relacji w systemie: człowiek - praca - otoczenie oraz praca - jednostka - inni ludzie ${ }^{10}$.

\section{Pedagogika pracy - rys historyczny}

Pedagogika pracy (niem. Arbeitspädagogik, ang. vocational education) w Polsce wykrystalizowała się w latach sześćdziesiątych-siedemdziesiątych ubiegłego wieku. Jej formalne początki przypadają na rok 1972, kiedy powołano Resortowy Instytut Kształcenia Zawodowego (IKZ). Na inauguracyjnym posiedzeniu Rady Naukowej Instytutu zdecydowano, że teoretycznym układem odniesienia dla działań nowo powstałego Instytutu będzie „pedagogika pracy" - nowa subdyscyplina naukowa w rozległym obszarze nauk pedagogicznych. Za wyborem nazwy pedagogika pracy przemawiały zdaniem Z. Wiatrowskiego - znaczące okoliczności:

- istnienie od wielu lat takich nauk traktujących o pracy człowieka, jak: filozofia pracy, psychologia pracy, socjologia pracy, fizjologia pracy, prakseologia i inne, zaliczanych obecnie do odpowiednich dyscyplin kierunkowych, a także do nieokreślonego jeszcze zbioru nauk o pracy;

- częste stosowanie nazwy "pedagogika pracy” w krajach zachodnich, szczególnie w Niemczech (już pod koniec XIX wieku);

- od wieków (zwłaszcza okresu Odrodzenia) traktowanie pracy jako bardzo znaczącego środka wychowania;

- stosunkowo bogaty już zakres wiedzy, a nawet - uznane przez odbiorców w kraju i za granicą - podstawy teorii kształcenia zawodowego, m.in. w postaci wykładni, autorstwa T.W. Nowackiego pt. Podstawy dydaktyki zawodowej11.

9 A. Bogaj, Człowiek w środowisku pracy, [w:] Pedagogika pracy, red. S.M. Kwiatkowski, A. Bogaj, B. Baraniak, Warszawa 2007, s. 35.

${ }^{10}$ J.E. Karney, Psychopedagogika pracy, Warszawa 2007, s. 8-9.

11 Z. Wiatrowski, Początki, rozwój i aktualny stan pedagogiki pracy w Polsce, [w:] Pedagogika pracy - tradycja $i$ wyzwania wspótczesności, red. S.M. Kwiatkowski, Radom-WarszawaBydgoszcz 2012, s. 73. 
Podstawowym pojęciem pedagogiki pracy jest - jak już wspomniano praca, która przejawia się w aktywności człowieka i jego zdolności do przekształcania świata, przy jednoczesnej umiejętności samodoskonalenia ${ }^{12}$.

Aczkolwiek pedagogika pracy w Polsce jest dyscypliną stosunkowo młodą, jej korzenie, jej rodowód sięga czasów najodleglejszych, ponieważ człowiek od zawsze żył i czynił wszystko, by zagwarantować sobie i najbliższym jak najlepsze warunki egzystencji. Przekształcał świat dzięki swojej aktywności i zdolnościom, jednocześnie samodoskonaląc się. Wartość pracy w życiu i wychowaniu człowieka dostrzeżono już w starożytności. Sentencje ówczesnych myślicieli, typu: „praca nie hańbi” (Hejzod), „praca wszystko przezwycięży” (Vergiliusz), czy "życie nie dało niczego śmiertelnym bez wielkiej pracy" (Horacy) przetrwały do dziś i nie straciły niczego ze swojej mądrości i aktualności.

W czasach nowożytnych bardzo wyraziście wyeksponowaną rangę pracy i jej wartości w wychowaniu znajdziemy w poglądach takich przedstawicieli utopijnego kierunku filozofii, jak: T. More, T. Campanella, F. Bacon i inni.

T. More - uważany za twórcę idei wychowania przez prace - sformułował postulat, aby młodzież (obojga płci) pracowała w rolnictwie, a dopiero później wybierała inne zawody. Jego Utopia to pochwała pracy i wychowania $\mathrm{w}$ równości i tolerancji.

J. Amos Komeński - prekursor współczesnej pedagogiki - w swoim systemie dydaktycznym i wychowawczym kładł duży nacisk na przysposobienie dziecka do pracy ręcznej (rzemiosła). Uważał, że przez pracę prowadzi najbardziej skuteczna droga do aktywizowania dziecka, eliminowania nudy, postulował zorientowanie dzieci $\mathrm{w}$ różnorodności prac zawodowych, aby łatwiej ujawniały się ich zamiłowania i skłonności ${ }^{13}$.

Za promotora idei wychowania przez prace w Polsce uważa się A. Frycza Modrzewskiego, który w swoim programie reform społecznych wielokrotnie i z całą siłą nawiązywał do pracy ludzkiej i jej roli w wychowaniu. Uważał, że do pracy należy przyzwyczaić dzieci od najwcześniejszych lat i systematycznie kontrolować jej wyniki. Postulował: „Wszystkich tedy przyzwyczaić by trzeba do jakiejś pracy”. „Kto zaś nie chce pracować, ten niech nie je”. Dwieście lat później problematyka wychowania przez pracę podjęta została, w znacznie szerszym zakresie, przez myślicieli i działaczy Komisji Edukacji Narodowej - G. Piramowicza, A. Popławskiego, A. Kamieńskiego, H. Kołłątaja i innych ${ }^{14}$.

\footnotetext{
12 S.M. Kwiatkowski, Pedagogika pracy, s. 13.

${ }^{13}$ Z. Wiatrowski, Podstawy, s. 23-24.

14 Tamże, s. 24-25.
} 
Wielkim orędownikiem przygotowywania młodzieży do pracy był S. Staszic, nazywany "ojcem polskiego szkolnictwa zawodowego". Z jego inicjatywy powstały liczne szkoły elementarne, średnie i wyższe, a także tzw. „szkoły niedzielne” i zawodowe - rzemieślnicze, rękodzielnicze i rolnicze.

W XIX wieku problematyka należąca do dziedziny zwanej dziś pedagogiką pracy interesowała pozytywistów, głoszących hasła "pracy organicznej" i „pracy u podstaw”. Swoistą rolę w spojrzeniu na pracę i jej funkcje w wychowaniu odegrały kontrowersyjne poglądy twórców marksizmu. Interesujące zaś były zapatrywania i dążenia prekursorów różnych odmian szkoły pracy, w tym głównie G. Kerschensteinera (Niemcy), J. Daweya (USA), H. Rowida w Polsce.

W 1857 roku Wojciech Jastrzębowski opublikował pracę zatytułowaną Rys ergonomii, czyli nauki o pracy, stając się tym samym nie tylko twórcą nowej, szczególnej nauki (o pracy), ale także zapoczątkował nowy, w pełni humanistyczny nurt badań nad pracą ludzką.

Nieco później Karol Adamiecki (obok F.W. Taylora i H. Fayola) tworzy teoretyczne podstawy organizacji i zarządzania (zwane wcześniej naukową organizacją pracy), a Tadeusz Kotarbiński zapoczątkowuje "szkicami praktycznymi" (1913) rozwój prakseologii, tj. nauki o sprawnym działaniu15.

W latach międzywojennych skutecznym orędownikiem kształtowania umiejętności praktycznych był Władysław Przanowski, twórca, nawiązującego do ideałów Komisji Edukacji Narodowej, Państwowego Instytutu Robót Ręcznych. W tym samym duchu działali Wiktor Ambroziewicz, Stefan Rudniański, Władysław Spasowski, Henryk Rowid - propagatorzy wychowania przez pracę oraz kształcenia politechnicznego. To właśnie ci pedagodzy, a jednocześnie działacze oświatowi - zdaniem S.M. Kwiatkowskiego mogą być uważani za prekursorów współczesnej pedagogiki pracy ${ }^{16}$.

W tworzeniu teoretycznych podstaw kształcenia zawodowego w okresie powojennym dominująca rola przypadła T.W. Nowackiemu, który już 1947 roku opublikował pozycję zatytułowaną Szkolnictwo zawodowe w nowej Polsce, zawierającą powojenny program kształcenia szeroko rozumianego, w tym szczególnie, kształcenia zawodowego. Wydane przez niego w 1971 roku Podstawy dydaktyki zawodowej okazały się nie tylko „podręcznikiem teoretyczno-praktycznym" [określenie autora - T.W. Nowackiego], ale przede wszystkim - monograficznym opracowaniem bardzo złożonego obszaru problemowego, występującego pod hasłem: kształcenie zawodowe. Ta "dojrzała teoria kształcenia zawodowego" stała się, zdaniem Z. Wiatrowskiego, punktem wyjścia dla nowej dyscypliny pedagogicznej - pedagogiki pracy ${ }^{17}$.

\footnotetext{
15 Tamże, s. 25-26.

${ }^{16}$ S.M. Kwiatkowski, Pedagogika pracy, s. 14.

17 Z. Wiatrowski, Podstawy pedagogiki, s. 27-29.
} 


\section{Pojęcie pedagogiki pracy}

Pedagogika pracy jako dyscyplina pedagogiczna ma stosunkowo krótką historię. Jej wykrystalizowanie wiąże się z powołaniem, we wrześniu 1972 roku, Instytutu Kształcenia Zawodowego (IKZ), z siedzibą w Warszawie. Inicjatorem, organizatorem IKZ i jego pierwszym dyrektorem (do 1983 roku) był prof. T.W. Nowacki, zwany powszechnie "ojcem chrzestnym" polskiej pedagogiki pracy ${ }^{18}$.

Uznając człowieka za kreatora wszelkich obszarów życia i działania, T.W. Nowacki pisał:

człowiek, poprzez pracę, stworzył nie tylko sam siebie, ale również własny świat (...). Wszystko wokół jest ogarnięte procesem nieustannych przemian, którym podlega stworzony przez człowieka świat. Na nikogo nie czeka gotowe, uładzone życie. Każde pokolenie musi budować swój własny świat, odpowiednio do osiągniętego poziomu techniki, na który złożyło się doświadczenie dziesiątków tysięcy lat (...). W każdym czasie człowiek podejmuje wyzwania wobec sił kosmicznych, staje wobec konieczności budowy, własnego, nowego świata, musi zdobyć się na maksymalne umiejętności twórcze. Ten człowiek, który poprzez pracę stworzył siebie, stworzył i tworzy dalej swój własny świat, jest człowiekiem - twórca. Homo creator nie jest jednostką, jest to człowiek zbiorowy, zorganizowany, dawniej w plemionach, obecnie we wspólnotach narodowych, tworzący razem gospodarstwo (bogactwo) narodowe i jego kulturę ${ }^{19}$.

Przyznając człowiekowi należny mu priorytet, nie tylko $\mathrm{w}$ dziele wychowania i przemian cywilizacyjnych, ale przede wszystkim w doskonaleniu siebie samego, T.W. Nowacki utwierdził kluczową rolę człowieka w teorii pedagogiki pracy. Podkreślał ważkość działań rozwojowych, które spoczywają na rodzinie i szkole, wyeksponował rolę edukacji w kształtowaniu umiejętności, zgodnych z zainteresowaniami i zamiłowaniami, przydatnymi w przyszłej pracy, wyborze szkoły średniej, przyszłego zawodu, miejsca pracy, w dalszym doskonaleniu się zawodowym, w dokształcaniu i samodoskonaleniu, a tym samym - $\mathrm{w}$ dążeniu do bycia wartościowym człowiekiem, pracownikiem, obywatelem. Tymi zagadnieniami (i zbliżonymi do nich problemowo) zajmuje się pedagogika pracy, a głównym celem autorki artykułu jest próba prezentacji tej dyscypliny pedagogicznej oraz wprowadzenie czytelnika w niektóre meandry strukturalne i badawcze tej nowej domeny.

Pierwszą, szeroko zakrojoną dyskusję nad istotą, przedmiotem badań i strategicznymi zadaniami pedagogiki pracy jako nowej dyscypliny na-

${ }^{18}$ Zob. dedykację: Whotdzie ..., [w:] Człowiek w pedagogice pracy, red. B. Baraniak, Warszawa 2012 , s. 5.

${ }^{19}$ T.W. Nowacki, Praca ludzka. Analiza pojęcia, Radom 2008, s. 43-44. 
ukowej przeprowadzono już w pierwszych miesiącach funkcjonowania IKZ, a znacznie rozleglejszą, pogłębioną merytorycznie - podczas Ogólnopolskiego Seminarium Pedagogiki Pracy w Złotowie w 1973 roku. Tu także podjęto próbę sformułowania definicji pedagogiki pracy. Pomimo faktu, że kierowano się kryteriami odrębności i samodzielności pedagogiki pracy jako dyscypliny naukowej, była to jednak definicja niezbyt udana, w której zabrakło szerokiej gamy zainteresowań oraz badań pedagogiki pracy jako subdyscypliny pedagogicznej ${ }^{20}$. Prace nad udoskonaleniem definicji pedagogiki pracy, spełniającej wszelkie wymogi naukoznawcze, ciągle trwają, gdyż zakres pojęciowy tej dziedziny wiedzy pedagogicznej znacznie się rozszerza, $\mathrm{w}$ wyniku przemian ekonomicznych i społecznych $\mathrm{w}$ naszym kraju - okresie aktywnego poszukiwania nowych, trafnych rozwiązań $\mathrm{w}$ reorganizowaniu gospodarki, w zarządzaniu pracą i życiem ludzi.

\section{Obszary problemowo-badawcze pedagogiki pracy}

Pod koniec 1972 roku T.W. Nowacki w swoim opracowaniu Zadania Instytutu Kształcenia Zawodowego zarysował dziesięć najważniejszych obszarów badawczych, które stały się wkrótce obszarami problemowymi polskiej pedagogiki pracy:

1) obszar obejmujący problematykę celów kształcenia i ich analizę $\mathrm{w}$ powiązaniu z przemianami kultury, gospodarki i struktury zatrudnienia;

2) problematyka podziału pracy i wyodrębnionych na tej podstawie zawodów, zasad i kryteriów dotyczących tych zagadnień;

3) treści kształcenia ustalone na podstawie charakterystyk zawodowych oraz ich dobór i układ (opracowywanie dokumentacji pedagogicznej, programy nauczania, formowanie wybranych treści w odpowiednie przedmioty);

4) zagadnienia wychowawcze, $z$ akcentem na wychowanie przez pracę (praktycznym owocem badań i eksperymentów powinien być system wychowawczy w zasadniczej szkole i liceum zawodowym);

5) obszar służebny nauczycielom, wyposażenie nauczycieli w metodyki i opracowania metodyczne dla przedmiotów zawodowych;

6) problematyka wyboru zawodu, poradnictwo zawodowe;

7) obszar obejmujący problematykę dokształcania i doskonalenia zawodowego;

8) problematyka dotycząca warunków prawidłowej realizacji procesów przygotowania i doskonalenia zawodowego; 
9) obszar problemowy, który tworzą sprawy kontroli i oceniania kształcenia oraz doskonalenia zawodowego;

10) obszar obejmujący zagadnienia pedeutologiczne, zwłaszcza, dotyczące nauczycieli szkół zawodowych ${ }^{21}$.

T.W. Nowacki w Leksykonie pedagogiki pracy (2004) dodaje obszar jedenasty - obszar badania rynku pracy ${ }^{22}$. Potwierdza to w wydanej, cztery lata później, pracy analitycznej: Praca ludzka. Analiza pojęcia (2008), uzasadniając ten fakt "poszerzaniem się terenów badawczych pedagogiki pracy”. Wzbogaca także dotychczasowe obszary badawcze pedagogiki pracy o kolejne dwa zagadnienia: Dwunastym obszarem problemowym - zdaniem T.W. Nowackiego - powinno być: „poradnictwo zawodowe”, a trzynastym - „bezpieczeństwo i higiena pracy" 23 .

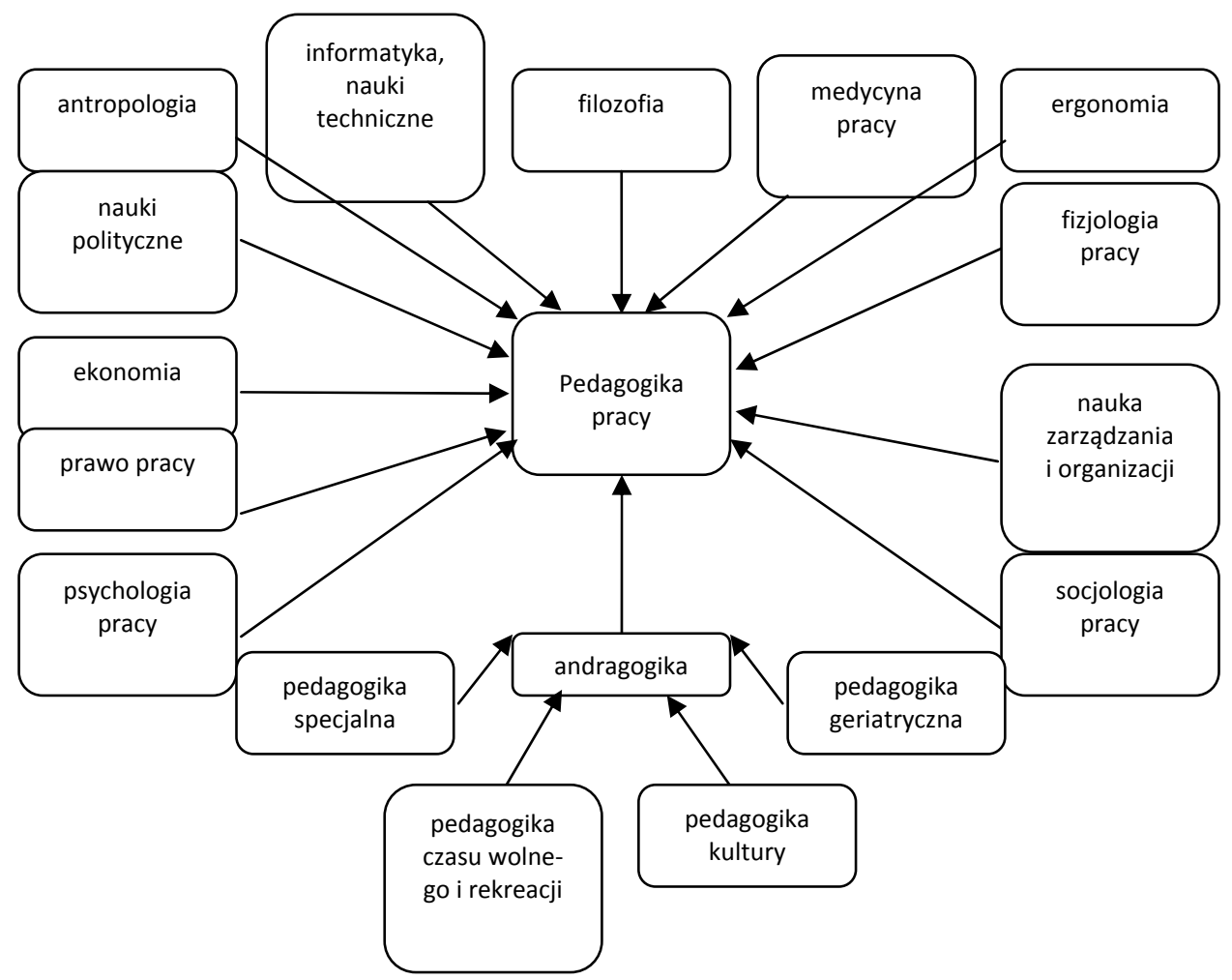

Ryc.1. Pedagogika pracy wśród innych dyscyplin naukowych (źródło: J.E. Karney, Psychopedagogika pracy, Warszawa 2007, s. 30)

${ }^{21}$ S. Kaczor, Instytut Kształcenia Zawodowego (1972-1990) w 40-leciu pedagogiki pracy, [w:] Pedagogika pracy, s. 26-27.

${ }^{22}$ T.W. Nowacki, Leksykon pedagogiki pracy, Radom 2004, s. 157.

${ }^{23}$ T.W. Nowacki, Praca, s. 113. 
Dopełnienie całokształtu materiału badawczego pedagogiki pracy o trzy ogromne zagadnienia badawcze autorka artykułu uważa za słuszne i celowe, bowiem wychodzi z założenia, iż lokalizacja pedagogiki pracy na styku z innymi naukami o wychowaniu i pracy ludzkiej sprzyja takiemu właśnie „wzbogacaniu", rozległego, już w tej chwili, "pola" problemowo-badawczego pedagogiki pracy o coraz to nowsze "podobszary”. Ponadto, pedagogika pracy stanowi taką dziedzinę wiedzy, która zajmując się szerokim aspektem życia i działalności człowieka, wykorzystuje doświadczenia innych nauk (por. ryc. 1), a one z kolei korzystają z metod i technik przyjętych $\mathrm{w}$ metodologii badań pracy (np. opis, pomiar i wartościowanie stanowisk pracy, charakterystyka treści i form pracy, tworzenie standardów kwalifikacyjnych, opis zmian zawodów, drogi rozwoju zawodowego itp.).

Wskazując na sztuczność podziału dziedzin wiedzy zajmujących się człowiekiem we współczesnym świecie pracy, J.E. Karney uważa, że współpraca naukowa specjalistów różnych dyscyplin, a także wspólne rozwiązywanie skomplikowanych problemów dnia codziennego integrują badaczy, przyczyniając się tym samym do bogatszego, szerszego, wnikliwszego oraz bardziej wszechstronnego rozumienia i rozwiązywania problemów człowieka we współczesnym środowisku zawodowym - profesjonalnej edukacji, w poradnictwie i doradztwie pracy, w pracy produkcyjnej, w usługach, zarządzaniu i innych ${ }^{24}$.

W połowie lat dziewięćdziesiątych XX wieku zmodyfikowano układ odniesienia terenów badawczych pedagogiki pracy, dokonując istotnego zwrotu w kierunku gospodarki rynkowej. Podkreślono i zaakcentowano rolę:

- małych i średnich prywatnych zakładów pracy;

- decentralizacji planowania rozmiarów kształcenia;

- miejsca szkół zawodowych w strukturze systemu edukacji;

- szeroko profilowanych kwalifikacji i kompetencji z uwzględnieniem mobilności zawodowych pracowników ${ }^{25}$.

Te nowe układy odniesienia, spowodowane zmianami ustroju społeczno-gospodarczego, Z. Wiatrowski uzupełnia o:

- ustrój społeczno-gospodarczy ewoluujący w kierunku współczesnego kapitalizmu;

- społeczeństwo obywatelskie, demokratyczne i pluralistyczne z akcentem na podmiotowość każdego człowieka, otwarte na wartości ogólnoludzkie i chrześcijańskie;

- dominującą rolę, a zarazem zasadę własności prywatnej;

- gospodarkę wolnorynkową zakładającą maksymalną przedsiębiorczość, mobilność, kompetencyjność i konkurencyjność;

\footnotetext{
${ }^{24}$ J.E. Karney, Psychopedagogika, s. 28-29.

25 S.M. Kwiatkowski, Pedagogika, s. 15.
} 
- daleko zaawansowaną demokratyzację i decentralizację w ogólnym kształcie życia państwowego i gospodarczego;

- transfer nowoczesnej techniki, technologii, organizacji i obsługi z uwzględnieniem szeroko prowadzonego doskonalenia zawodowego;

- transformację ilościową i jakościową zasobów kadr pracowniczych, szczególnie w zakresie przekwalifikowania, dostosowania do nowych potrzeb i aktywnej oraz racjonalnej polityki kadrowej26.

Ponieważ pedagogika pracy obejmuje swym zainteresowaniem człowieka pracy $\mathrm{w}$ różnych fazach jego życia i rozwoju, a nie tylko wchodzących $\mathrm{w}$ życie zawodowe, centralnym problemem tej dziedziny wiedzy w zmiennych warunkach społeczno-gospodarczych stało się - zdaniem J. E. Karney kształcenie i wychowanie ludzi oraz przygotowanie ich do samokształcenia i samowychowania $\mathrm{w}$ aspekcie pracy zawodowej. Obejmuje ono osoby:

- przygotowujące się do podjęcia pracy (w różnym wieku i do różnych zawodów);

- pracujące zawodowo (adaptacja zawodowa i doskonalenie);

- opuszczające trwale miejsce pracy (zwolnienia, renty, emerytury).

Obecne warunki, po transformacji ustrojowo-społeczno-gospodarczej, rzutują w dużej mierze na to, iż pedagogika pracy - co podkreśla J.E. Karney - zajmuje się przede wszystkim zawodami wymagającymi od pracownika: wysokich kwalifikacji i kompetencji, wysokiego morale, wysokiego poziomu intelektualizacji, dużych sprawności $w$ podejmowaniu decyzji zwłaszcza złożonych i trudnych, dotyczących procesu pracy, pracowników oraz organizacji jako specyficznego systemu społecznego.

W opinii cytowanej autorki, wśród najczęściej wymienianych zadań obecnej pedagogiki pracy znajdują się:

- Wpływ pracy na człowieka i sposoby radzenia sobie z oddziaływaniem negatywnym. Organizacja a praca.

- Zatrudnienie, praca, bezrobocie w erze globalizacji.

- Dobór zawodowy w warunkach zmian rynku pracy.

- Kwalifikacje i kompetencje zawodowe.

- Rozwój i wzrost zawodowy, kreowanie karier, zwłaszcza przez edukację.

- Orientacja, poradnictwo i doradztwo zawodowe.

- Kształcenie, doskonalenie, szkolenia i samokształcenie zawodowe.

- Edukacja menedżerów.

- Profesjonalizm w pracy. Badanie i opis pracy. Standardy kwalifikacji i kompetencji zawodowych. 
- Metody edukacji dorosłych i zawodowego kształcenia ustawicznego. Programowanie dydaktyki zawodowej.

- Nauczyciele pracy i zawodu (train the trainers, coaching, assessment $\mathrm{i}$ in.).

- Problemy zarządzania wiedzą i zarządzania edukacją w organizacji.

- Społeczne problemy człowieka w organizacji. Pracownik a inni członkowie organizacji27.

Monumentalne zagadnienia problemowo-badawcze pedagogiki pracy, powiązane z kolejnymi etapami edukacji i pracy zawodowej człowieka, pozwoliły wyodrębnić cztery działy tej dziedziny.

1. Kształcenie przedzawodowe - okres wychowania dziecka, a następnie ucznia „przez pracę" $\mathrm{i}$ „do pracy”, prowadzone przez dom rodzinny, przedszkole, szkołę podstawową, gimnazjum, liceum, a także placówki opiekuńczo-wychowawcze, organizacje młodzieżowe i wyznaniowe; w obszarze tym zawiera się również preorientacja oraz orientacja i poradnictwo zawodowe.

2. Kształcenie prozawodowe - okres, w którym uczeń poznaje specyfikę różnych zawodów, zaczyna rozumieć sens pracy, zdobywa wykształcenie ogólne, zbliża się do wyboru drogi zawodowej, ale jeszcze nie uzyskuje żadnych kwalifikacji zawodowych. Ten typ kształcenia (i problemy z nim związane) jest charakterystyczny dla funkcjonującego w obecnej strukturze systemu edukacji, liceum profilowanego.

3. Kształcenie zawodowe - okres nauki w zasadniczej szkole zawodowej lub technikum prowadzący do uzyskania kwalifikacji zawodowych; czas systematycznego zdobywania wiedzy umożliwiającej kształtowanie umiejętności zawodowych; okres, w którym krystalizują się cechy psychofizyczne i postawy dotyczące pracy zawodowej. W sferze tej mieści się cała struktura treści dydaktycznych: cele, treści, programy kształcenia i wychowania zawodowego, proces kształcenia zawodowego, formy, metody i środki kształcenia zawodowego, warunki skuteczności i wyniki kształcenia, w tym zagadnienia powodzeń i niepowodzeń szkolnych uczniów szkół zawodowych, pomiar osiągnięć, poradnictwo zawodowe, a także wymagania rynku pracy i związane z nimi losy absolwentów.

4. Kształcenie ustawiczne dorostych - okres pracy zawodowej i nierozerwalnie związane z nim ciągłe dokształcanie i doskonalenie; obejmuje problemy edukacyjne pracujących i bezrobotnych, szkolenia, polegające na zdobywaniu nowych kwalifikacji, ułatwiających zmianę zawodu; skupia uwagę na adaptacji społeczno-zawodowej, identyfikacji z zawodem i zakładem pracy, stabilizacji zawodowej; zajmuje się zagadnieniami stosunków międzyludzkich w zakładzie pracy, strategią edukacyjną - uczenia się przez całe życie, wiodącą do osiągnięcia mistrzostwa w zawodzie ${ }^{28}$.

27 J.E. Karney, Psychopedagogika, s. 31-33.

${ }_{28}$ S.M. Kwiatkowski, Pedagogika pracy, s. 15-16. 
Pomimo ogromnej złożoności i rozległości obszarów problemowo-badawczych pedagogiki pracy, Z. Wiatrowski wskazuje zagadnienia charakterystyczne, wymagające zgłębienia $\mathrm{w}$ przyszłości. Oto kilka $\mathrm{z}$ tych najistotniejszych, koncentrujących się wokół:

- sylwetki człowieka, jakiego chcemy wychować;

- zadań zawodowych, jakie będzie wykonywać absolwent określonej szkoły zawodowej;

- treści, metod i środków kształcenia, dokształcania oraz doskonalenia zawodowego;

- warunków osobowych i materialnych przygotowania człowieka do pracy;

- skuteczności kształcenia, dokształcania i doskonalenia zawodowego;

- efektywności działań edukacyjnych w miejscu pracy ${ }^{29}$.

Ponieważ obszary problemowo-badawcze poszczególnych działów pedagogiki pracy mogą ulegać zmianom wraz ze zmiennym charakterem współczesnych realiów edukacyjnych i rynkowych, uwaga pedagogów pracy w najbliższych latach - zdaniem S.M. Kwiatkowskiego - powinna skupić się przede wszystkim na problemach związanych z:

- poradnictwem zawodowym;

- zawodoznawstwem;

- standardami (normami) kwalifikacji zawodowych;

- ideą kształcenia ustawicznego - „uczeniem się przez całe życie” 30 .

W dotychczasowych klasyfikacjach obszarów problemowych i działań pedagogiki pracy przeplatają się aspekty naukowoznawcze i edukacyjne. Skłoniło to Z. Wiatrowskiego do ustalenia nowego podziału pedagogiki pracy, uwzględniającego te dwa podejścia klasyfikacyjne, oparte na następujących wyznacznikach:

I. Problemy i zadania pedagogiki pracy oraz jej dziaty w kontekście naukoznawczym:

- pedagogika pracy jako subdyscyplina naukowa i dyscyplina pedagogiczna;

- teoretyczne i metodologiczne podstawy pedagogiki pracy;

- kształcenie i wychowanie przedzawodowe oraz prozawodowe;

- edukacja zawodowa (w wersji założonej i rzeczywistej);

- rynek pracy, zatrudnienie, praca zawodowa i bezrobocie - prawidłowości oraz patologie;

- kształcenie ustawiczne dorosłych $\mathrm{w}$ okresie ich aktywności zawodowej;

${ }^{29}$ Z. Wiatrowski, Podstawy, s. 33-34.

${ }^{30}$ S.M. Kwiatkowski, Pedagogika pracy, s. 16. 
- problemy humanizacyjne i społeczno-wychowawcze oraz edukacyjne zakładu pracy;

- reprezentacja instytucjonalna i personalna pedagogiki pracy oraz innych nauk o pracy;

- pedagog pracy jako specjalista oraz główny realizator idei i zadań pedagogiki pracy.

II. Pedagogika pracy w aspekcie edukacyjnym:

- kształcenie przedzawodowe i prozawodowe;

- kształcenie zawodowe - edukacja zawodowa;

- kształcenie ustawiczne dorosłych w okresie ich aktywności zawodowej31.

Ponad czterdzieści lat polskiej pedagogiki pracy to dobry czas na prezentację dorobku tej dyscypliny - czas, kiedy można już wyraźnie określić jej dominujące podejścia teoretyczne i główne nurty badawcze, zgodne z aktualnym i nowoczesnym spojrzeniem na przebieg idei „uczenia się przez całe życie" zarówno w wymiarze zawodowym, jak i indywidualnym, osobniczym, właściwym tylko danej jednostce.

S.M. Kwiatkowski dokonując systematycznego przeglądu osiągnięć pedagogiki pracy, wskazuje najważniejsze zespoły problemów tej dziedziny:

- w obszarze zawodoznawstwa:

- rozwój zawodowy człowieka, a w tym motywy wyboru zawodu, adaptacja zawodowa, aktywność zawodowa oraz droga awansu zawodowego;

- nowe zawody (obszary powstawania nowych zawodów, w tym zawodów w UE);

- nowe formy zatrudnienia (elastyczne formy zatrudnienia i organizacji pracy);

- klasyfikacja zawodów (klasyfikacja gospodarcza i szkolna - wzajemne relacje);

- relacje: kształcenie zawodowe - rynek pracy (rola rynku pracy w procesie modyfikowania struktury i treści kształcenia);

- lokalne i globalne cele kształcenia zawodowego (wzajemne relacje: lokalny i globalny rynek pracy);

- kwalifikacje zawodowe (poziomy i modele kwalifikacji);

- analiza procesu pracy (metody wartościowania pracy);

- bilans kwalifikacji (metodologia oceny kwalifikacji pracowników;

- w obszarze poradnictwa zawodowego:

- analiza funkcjonowania różnych modeli poradnictwa zawodowego;

- kształcenie, dokształcanie i doskonalenie doradców zawodowych;

- relacje między kształceniem ogólnym a zawodowym;

${ }^{31}$ Z. Wiatrowski, Poczatki, rozwój i aktualny stan pedagogiki pracy w Polsce, [w:] Pedagogika pracy, s. $78-79$. 
- metody, techniki i narzędzia do określania predyspozycji poszczególnych uczniów ${ }^{32}$.

Z kolei, Z. Wołk w swoich rozważaniach dotyczących przedmiotu badań pedagogiki pracy akcentuje znaczenie współczesnego rynku pracy. Uznając rynek pracy za pojęcie kluczowe, które symbolizuje zarówno zakłady pracy, pracodawców, jak i pracobiorców, sądzi, iż występują tutaj zjawiska godne rozważnej uwagi pedagogów pracy. Dotyczą one w większości relacji, jakie między nimi zachodzą 33 .

\section{Zakończenie}

Niniejszy artykuł powstał jako odpowiedź na prośby studentów pedagogiki o syntetyczne przedstawienie, $\mathrm{w}$ jednym miejscu, aktualnego kształtu pedagogiki pracy we współczesnej Polsce. Żywię nadzieję, że zaprezentowane tu zagadnienia przybliżyły zainteresowanym tę nową dyscyplinę naukową.

Warto w tym miejscu wspomnieć również o ideale osobowym pedagoga pracy i jego roli profesjonalnej. Przyjęto bowiem uważać, że pedagog pracy to pracownik zajmujący się działalnością pedagogiczną, umiejący i chcący pracować z młodzieżą oraz dorosłymi nad wykształceniem u nich postawy dobrego człowieka, dobrego obywatela i dobrego pracownika zarazem, przy tym pracownika osiągającego mistrzostwo w zawodzie oraz pełne zadowolenie $\mathrm{z}$ wykonywania powierzonych mu zadań zawodowych, naukowych i społecznych ${ }^{34}$. Wydaje się, że to dobre motto dla wszystkich obecnych i przyszłych pedagogów pracy.

Kończąc refleksje z zakresu pedagogiki pracy, pragnę zacytować prof. Z. Wiatrowskiego, który tak wspomina narodziny nowej dyscypliny naukowej:

(...) tworzenie nauki to postępowanie wyjątkowo trudne, pracowite i wielce odpowiedzialne. Kształtowano nie tylko podstawy teoretyczne i metodologiczne pedagogiki pracy, ale również postawy ludzi nauki, a tym bardziej profesjonalistów w dziedzinie pedagogiki pracy. $W$ tej złożonej aktywności naukowej i edukacyjnej, $\mathrm{w}$ toku spotkań seminaryjnych i innych (...) zawsze też pamiętano o ideale osobowym pedagoga pracy i jego roli profesjonalnej. Przyjęto bowiem uważać, że pedagog pracy to pracownik zajmujący się działalnością pedagogiczną, umiejący i chcący pracować z młodzieżą i z dorosłymi nad wykształceniem u nich postawy dobrego człowieka,

32 W. Furmanek, Humanistyczna pedagogika pracy. Charakterystyka dyscypliny naukowej, Rzeszów 2013, s. 391-392.

${ }_{3}$ Z. Wołk, Zadania pedagogiki pracy wobec zmian wspótczesnego świata, Pedagogika Pracy, 2003, 45, s. 57-67.

${ }^{34}$ Z. Wiatrowski, Początki, s. 83-84. 
dobrego obywatela i dobrego pracownika zarazem, przy tym pracownika, osiągającego mistrzostwo $\mathrm{w}$ zawodzie oraz pełne zadowolenie $\mathrm{z}$ wykonywania powierzanych mu zadań zawodowych, naukowych i społecznych ${ }^{35}$.

\section{BIBLIOGRAFIA}

Baraniak B. (red.), Człowiek w pedagogice pracy, Warszawa 2012.

Bezrobocie rejestrowane. I kwartat 2015 r., GUS, Warszawa 2015 na: file://C:/ Users/WSE/Downloads/bezrobocie_rejestrowane_1kw2015.pdf [dostęp: 1.08.2015].

Bogaj A., Człowiek w środowisku pracy, [w:] Pedagogika pracy, red. S.M. Kwiatkowski, A. Bogaj, B. Baraniak, Warszawa 2007.

Furmanek W., Humanistyczna pedagogika pracy. Charakterystyka dyscypliny naukowej, Rzeszów 2013.

Kaczor S., Instytut Kształcenia Zawodowego (1972-1990) w 40-leciu pedagogiki pracy, [w:] Pedagogika pracy - tradycja i wyzwania wspótczesności, red. S.M. Kwiatkowski, RadomWarszawa-Bydgoszcz 2012.

Karney J.E., Podstawy psychologii i pedagogiki pracy, Pułtusk 2004.

Karney J. E., Psychopedagogika pracy, Warszawa 2007.

Kwiatkowski S.M., Pedagogika pracy jako subdyscyplina pedagogiczna, [w:] Pedagogika pracy, red. S.M. Kwiatkowski, A. Bogaj, B. Baraniak, Warszawa 2007.

Nowacki T.W., Leksykon pedagogiki pracy, Radom 2004.

Nowacki T.W., Praca ludzka. Analiza pojęcia, Radom 2008.

Okoń W. (red.), Nowy stownik pedagogiczny, Warszawa 2001.

Pomykało W. (red.), Encyklopedia pedagogiczna, Warszawa 1996.

Wiatrowski Z., Podstawy pedagogiki pracy, Bydgoszcz 2005.

Wiatrowski Z., Początki, rozwój i aktualny stan pedagogiki pracy w Polsce, [w:] Pedagogika pracy - tradycja i wyzwania wspótczesności, red. S.M. Kwiatkowski, Radom-WarszawaBydgoszcz 2012.

Wołk Z., Zadania pedagogiki pracy wobec zmian wspótczesnego świata, Pedagogika Pracy, 2003.

35 Tamże. 